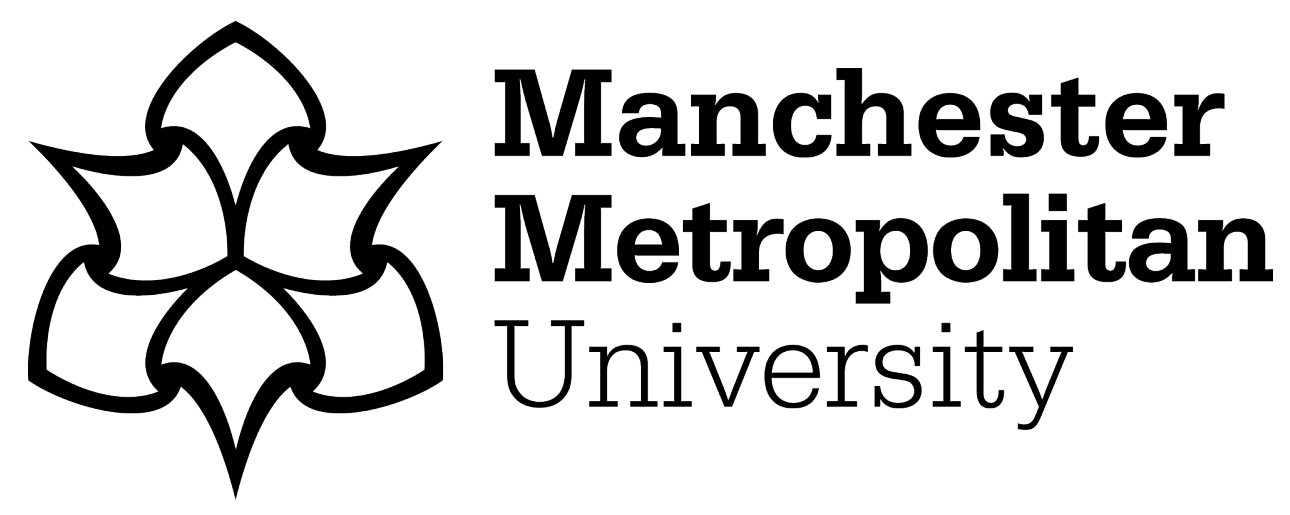

Edwards, S ORCID logoORCID: https://orcid.org/0000-0002-1433-8243 (2020) Special relationships: romance, race, and the friendly invasion in film and television, 1941-1996. Journal of Transatlantic Studies, 18 (3). pp. 353381. ISSN 1754-1018

Downloaded from: https://e-space.mmu.ac.uk/629005/

Version: Accepted Version

Publisher: Palgrave Macmillan (part of Springer Nature)

DOI: https://doi.org/10.1057/s42738-020-00053-y

Please cite the published version 


\section{Special Relationships: Romance, Race, and the Friendly Invasion in Film and \\ Television, 1941-1996}

\section{Sam Edwards}

The story of the wartime 'friendly invasion' by American soldiers has been a staple of British popular culture since at least the end of the Second World War. Transatlantic love affairs and sexual encounters between Americans and Britons during the conflict were central to the origins - and lived experience - of the 'special relationship'. This article assesses how such events and episodes have been reimagined in post-war popular culture. By examining various films, novels and television series from the 1940s to the 1990s, the article explores how cultural representations of the 'friendly invasion' - and especially of Anglo-American romance - have played an important role in mediating the discourses, disputes and shifting realities of contemporary Anglo-American relations. In doing so, the article contributes to on-going work interrogating anew the cultural history of the special relationship.

Keywords: Second World War; war films; transatlantic romance; memory and representation

By the eve of D-Day, June 6, 1944, there were 1,650,000 American service-personnel in Britain. ${ }^{1}$ To be sure, Americans had come before: after the Revolution, thousands of 'loyalists' fled hearth and home in the colonies, crossed the Atlantic and settled in England, many putting down roots in the Southwest. ${ }^{2}$ During the First World War, the vast majority of American soldiers shipped to Europe landed first in Britain, with most walking down gangplanks in Liverpool prior to despatch to the Front in France. These were certainly important precedents (especially the experience of 1917-18), but what happened during the Second World War was on a different scale. Known to history as the 'friendly invasion', the American military presence in Britain between 1942 and 1945 represented, in effect, an 'occupation'. For, as David Reynolds has argued, thinking of the wartime American presence in these terms rightly implies 'similarities with other armies on foreign soil, friendly as well as hostile, who are all, to some extent, over sexed and over here'. ${ }^{3}$

This latter language recalls a popular British wartime witticism. As more than one Briton was (supposedly) heard to declare, the problem with the 'Yanks' was that they were 
'over paid, over fed, over-sexed, and over here'. Such comments revealed a key feature of the American military presence that provoked engaged discussion among the British public then and later: what Reynolds refers to as the 'headaches' presented to the authorities by AngloAmerican sexual and romantic liaisons. ${ }^{4}$ Two forms of 'relationship' were considered especially problematic. The first was illicit and concerned the meetings between American GIs and British prostitutes. Such meetings worried the (male) military hierarchy because of perceived immorality, but also because of concerns over the extent to which one possible outcome, venereal disease, might compromise military effectiveness. The second type romantic relationships between American men and British women, not infrequently leading to love and marriage - similarly caused some senior military officers to fear a decline in military effectiveness, whilst others worried that naïve American youth was being hoodwinked by scheming British womanhood (assumed to be after American money, and American citizenship). ${ }^{5}$ Like the friendly invasion more generally, the historiography of such wartime relationships is extensive, ${ }^{6}$ with the subject of so called 'GI Brides' interrogated in particular depth and detail. ${ }^{7}$

Despite all this scholarship, the many cultural representations of such encounters have not received similarly detailed attention. ${ }^{8}$ This article explores how the friendly invasion - and especially the question of male-female romantic liaisons ${ }^{9}$ - has been depicted in British film and television from the 1940 s through to the $1990 \mathrm{~s}^{10}{ }^{10}$ In doing so, and via a close reading of text and context, I develop two connected observations. First, the friendly invasion has been such a persistent subject of interest in British popular culture that it in fact constitutes a previously unacknowledged subgenre within Second World War-themed film and television. Second, I argue that the significance of this subgenre lies in the extent to which it does far more than merely recount an interesting episode in transatlantic history. Rather, given that wartime transatlantic relations were informed by a gendered political discourse - the Churchillian 
'special relationship' - these stories of Anglo-American love and romance have actually involved critical commentary on what Emily Rosenberg has identified as the overlapping fields of sexual and international politics. ${ }^{11}$ As such, these cultural texts are as revealing of contemporary ideas regarding Anglo-American relations as are the far more frequently quoted pronouncements of prime ministers and presidents. ${ }^{12}$ Put differently, these audio-visual representations expose the ways in which powerful cultural producers have sought to understand - and depict - the Anglo-American relationship. And due the persistent currency of certain themes, ideas and issues they are thus also suggestive of how contemporary audiences have understood, or, at the very least, been asked to understand the dynamics at the heart of this relationship.

This is apparent most often in the workings of a recurring plot device: a 'love triangle' involving a British woman - or, very occasionally, an American woman - usually romantically pursued by both a British and American serviceman. Of course, such a device is by no means peculiar to the friendly invasion subgenre (love triangles are a popular conceit in Hollywood romances). But read in the context of the twentieth-century Anglo-American balance of power, and assessed with reference to what Frank Costigliola has argued is the important role played by elite-level romance in the very construction of the 'special relationship', ${ }^{13}$ such depictions gain new significance. They become widely disseminated cultural texts in which those issues at the very centre of Anglo-American relations - power, control, constructions of masculinity and femininity - are imagined, projected and examined. ${ }^{14}$ With this in mind, I identify three distinct phases within the subgenre: 1940s era explorations of a transatlantic parity of power; critiques of wartime colonisation in the 1960s; and a 1980s and 1990s nostalgia shaped by certain absences and omissions, especially the long marginalised presence in wartime Britain of African American service personnel. 


\section{Special Relationships? The Friendly Invasion in wartime documentary and feature film,}

1941-1946

The wartime friendly invasion - 'the greatest single encounter between ordinary Americans and ordinary Britons' - had a regional flavour. ${ }^{15}$ Operation Bolero - the name given to this US troop build-up (which began in 1942) - originally was intended to deliver large numbers of infantry to the south coast of England in readiness for a cross-Channel attack. But shifts in Allied strategy (the invasions of North Africa, Sicily and Italy) changed the composition of American troopships headed to Britain, with increasing numbers of aircrew and connected supply and logistics personnel taking precedence. In turn, this produced two initial concentrations: one in eastern England, where the 8th Air Force of the United States Army Air Force (USAAF) established itself on around 70 newly constructed airfields. ${ }^{16}$ Northern Ireland and north-west England (especially Lancashire and Cheshire) constituted a second area of American occupation - this was the site of major ports and, in time, large supply depots. A third concentration later developed in early 1944 along the south-coast (as first planned). ${ }^{17}$

As large numbers of Americans began arriving in Britain, both national governments devoted significant resources to fostering mutual understanding. The War Department in Washington issued an 'instructional' manual distributed to those troops heading to the United Kingdom. Reminding readers that the British 'are tough' and not 'panty-waists', the manual attempted to explain British culture, attitudes, mannerisms, and recent history. ${ }^{18}$ The British Council reciprocated, publishing a volume explaining to 'overseas forces' the 'English and their country'. After acknowledging that the 'English have for centuries been a puzzle', the author - Thomas Burke - proceeded to explain as best he could the country's 'racial characteristics', its architecture, its people (full of pluck and under-stated patriotism), its 
landscape (green, outside of the towns), and its various 'institutions' (the pub, football matches, Sunday afternoons). ${ }^{19}$

Pre-war popular culture both helped and hindered these efforts to cultivate AngloAmerican understanding. In the United States, Hollywood studios had spent several years before the outbreak of hostilities developing a particular genre of 'British film' in which a popular conceit of Victorian literature - a bewildered American encounters British manners, accents and customs - was used to good effect. ${ }^{20}$ As the genre dictated, these films often examined such 'encounters' via stories of Anglo-American love and romance. Take, for instance, such classics as $A$ Yank at Oxford (1938) and A Yank at Eton (1942), key elements of which were recycled in various wartime films, including A Yank in the West Country (1945) and, rather more famously, the 1941 production $A$ Yank in the RAF.

In the latter, a Daryl Zanuck project directed by Henry King, isolationist-era AngloAmerican relations were interrogated via a transatlantic love triangle involving a dashing RAF officer, Wing Commander John Morely (John Sutton), an overconfident but fundamentally decent Yank, Tom Baker (Tyrone Power) and a principled young American woman 'over here' and enlisted in the WAAFs, Carol Brown (Betty Grable). ${ }^{21}$ In a deliberate effort to encourage more overt American support for Britain (a popular project amongst the Hollywood elite), ${ }^{22}$ Zanuck has Baker depicted as a rather mercenary pilot ferrying US built aircraft across the Canadian border. Having decided on a whim to pocket more cash by flying a bomber direct to Britain, Baker then meets his old girlfriend, Brown, in London, and in an effort to impress enlists in the RAF. A friendly love rivalry duly develops between Baker and an English comrade (Morely), both of whom compete for the affections of Brown, although the exuberant American ultimately wins her heart. Crucially, however, whilst losers in love the British nonetheless still get something of what they want, which is of course young American manhood committed to their national defence. For having originally enlisted in the RAF as a means to 
impress Brown, by the film's end Baker is found to have developed some principles: the British cause, he believes, is also now his. He thus transfers to Fighter Command, only to be shot down over Dunkirk. After a bit of derring-do he then arrives on the English coast to a warm embrace from Brown, who had feared his untimely demise. Morely is there too, pleased to see the return of his friend and apparently holding no grudges about his recent romantic 'defeat'. And so, now committed to both Brown and Blighty, Baker is ready to do his 'bit' in the forthcoming Battle of Britain. ${ }^{23}$

Released two months before the attack on Pearl Harbor when isolationism remained a powerful force in American politics, $A$ Yank in the $R A F$ offered an invaluable mechanism for transatlantic communication and was well-received as such. The influential film critic of The New York Times, Bosley Crowther, remarked that the film was full of 'thrilling action' and 'tingling suspense', going on to commend the 'lively adventure-romance' at the heart of the story (Crowther's only criticism was that there was perhaps 'a little too much romance and not enough scrapping'). ${ }^{24}$ At the same time, in its exploration of a 'cocky young American flyer ... roaring off over calm English country' the film also anticipated - and mediated - some of what would follow when the US formally entered the war. ${ }^{25}$ Little wonder that once Operation Bolero was underway the American military enlisted the Hollywood film industry in an effort to help its soldiers appreciate the country, culture and conflict into which they had arrived. ${ }^{26} \mathrm{In}$ eastern England, for example, which by 1944 had been occupied by half a million Americans of the 8th Air Force, the stars of Hollywood were especially apparent. Director William Wyler (already famous for his 1939 pro-British film, Mrs Miniver) was given a commission in the USAAF and later produced one of the great war documentaries, Memphis Belle (1944). ${ }^{27}$ As Wyler donned helmet and flak jacket to capture arresting footage of combat in the blue azure, other Hollywood A-listers similarly contributed their time - and risked their lives - in the interests of the Anglo-American war effort. Based at Polebrook in Northamptonshire, Clark 
Gable flew five missions as an air-gunner during 1943; Jimmy Stewart, by this point already well-known for such Depression-era classics as Mr Smith Goes to Washington (1939), was commissioned into the 8th Air Force and rose to the rank of lieutenant colonel. ${ }^{28}$ The cultural and political power of Hollywood, the role already played by inter-war film in cultivating transatlantic 'understanding', and the fact that numerous American directors, producers and actors were themselves 'over here' combined to ensure that US military leaders quickly identified the propaganda potential of film. ${ }^{29}$

The 1943 film Welcome to Britain is a case in point. A collaboration between the US Army and the British Ministry of Information, the film sees actor Burgess Meredith play the role of a knowing 'Yank' explaining to his newly arrived comrades how to 'deal' with the locals. In the hands of British director Anthony Asquith, what follows is a series of vignettes in which Meredith first gets it 'wrong' so that he can then show viewers how to get it 'right'. Soldiers were counselled that it was unwise to be boastful in village pubs; that, if invited into a British home, they should avoid accidentally consuming all the food; and that, above all, they must avoid insults and indiscretions. This is very much the 1942 instructional manual put on film, with one notable exception. Where the former only referenced British women as home front heroines doing their bit for King and Country, the latter sees them in a rather different light: as both attraction and distraction. At the film's start, for example, Meredith decides to visit a 'country pub'. As he strolls towards 'Taylor, Walkers' for a 'prize beer' a young woman (Carla Lehman) crosses his path. Meredith smiles, gawks, turns to camera, and with a knowing look declares 'We'll get to that later'. But in fact we do not; aside from a passing suggestion that those wearing the uniform of Uncle Sam should avoid flirting with barmaids, the issue of how American soldiers should conduct themselves with British women remains largely unexamined throughout the 40-minute film. It thus ends up accidentally affirming a key contemporary concern: that American soldiers would see British women as 'targets' to be 
pursued - Lehman's (silent and unnamed) character is seen at various other moments in the film always subject to the 'male gaze'. ${ }^{30}$

As government-sponsored propaganda agencies produced films intended to promote Anglo-American understanding so too did the British film industry. In A Canterbury Tale (1944), for example, a 'meandering and sometimes quite inexplicable' ${ }^{31}$ Michael Powell and Emeric Pressburger project, another key feature of the American presence - which often saw the US military overwhelm small rural populations - is skilfully displaced. ${ }^{32}$ The plot sees a recently arrived American soldier - Sergeant Bob Johnson, played by real life Yank, Sergeant John Sweet - take a train to Canterbury, but, due to a misunderstanding he get gets off at the wrong stop: Chillingbourne, a (fictional) village well off the beaten track. Disorientated on a dark platform and in search of accommodation for the night, he joins up with a British soldier, Sergeant Peter Gibbs (Dennis Price) and a London shop-worker turned 'Land Girl', Alison Smith (Shelia Simm). But on arrival in the village they are 'attacked': Smith discovers that someone has put glue in her hair. Following this (clearly sexualised) assault, the three set out in pursuit of the mysterious 'glue-man' who wanders Chillingbourne at night discharging his sticky substance into the hair of any woman seen in the company of a soldier. ${ }^{33}$ What follows is part detective story, part cinematic celebration of an ancient England threatened by machinery and modernity, although not - significantly - by invading American masculinity. Indeed, whilst the film had clear potential for our detective trio to be disrupted by love rivalries, it is actually largely uninterested in questions of Anglo-American sex or romance. Instead, we get lingering shots of the Kent downs and paeans to England's rural arcadia, but little sense that a 'friendly invasion' was then underway. Our American hero is, in fact, depicted as merely the latest in a long line of pilgrims to have made their way to Canterbury since the days of Chaucer. In one revealing scene Sergeant Johnson even discovers that he shares a common rustic language with a local carpenter, a moment of transatlantic understanding which belies 
George Bernard Shaw's suggestion that Americans and Britons were two people separated by a 'common language'.

The country's ability to accommodate a newly arrived American presence - implied in A Canterbury Tale - is also suggested by some of the other British productions of 1944-45. Several also now began to examine in more detail the gendered dynamics of the invasion, especially in terms of relationships between American men and British women. In Welcome, Mr Washington (1944), for example, directed by Leslie Hiscott and released in May 1944, two British sisters made penniless by their father's death decide to lease some of their farm to the American military, for use as an airbase. ${ }^{34}$ The Americans invade, occupy, and change local life and landscape. But after initial confusions and antagonisms, both sisters eventually fall for American airmen. Here, therefore, British patriarchy (the deceased father) gives way to that of the Americans, and the sisters are saved from spinsterhood and pecuniary hardship by American benevolence, an idea that appears to have been appreciated at the time. ${ }^{35}$ One review specifically noted that the film gave 'our American visitors a well-timed pat on the back' ${ }^{36}$

A similar 'pat' was offered in The Way to the Stars (1945). Directed by Anthony Asquith (familiar from his role on Welcome to Britain), and starring John Mills as Pilot Officer Peter Penrose and Michael Redgrave as his friend Flight Lieutenant David Archdale, the film again tells the story of a British airbase - Halfpenny Field - taken over by the USAAF. At the start, Halfpenny Field is clearly and firmly English: Union flags fly, the Battle of Britain rages, and salt-of-the-earth NCOs offer advice whilst tugging at forelocks. After this lengthy scenesetting - including the marriage of Archdale to a local hotelier, Miss Todd (Rosamund John) the story flashes forward to the summer of 1942 and the arrival of the first American aircrew. Needing a base from which to launch their first bombing raids, the Americans are given Halfpenny Field. Their arrival duly produces the mutual mocking of accents and mannerisms; it also produces potential tensions focused around local women. The intent of the Americans 
is identified early, with two wise-cracking Yanks discussing their 'prospects': 'And whaddya know Joe, they got a lotta women here, on the Station'. But the predatory pursuit of British womanhood is ultimately offset by a love triangle of a rather unusual sort. Miss Toddy, widowed after Archdale's death in combat and left to raise their young baby - Peter - alone, develops a platonic relationship with an American officer, Captain Johnny Hollis (Douglass Montgomery).

A Brief Encounter-esque story of romance and restraint follows during which Hollis becomes a father-figure for young Peter even though Archdale always lingers in the background (his picture stands on the mantle-piece as the two 'lovers' talk). Even this essentially benign threat to the male-bonding of the Anglo-American alliance - as seen in the developing friendship between Hollis and Penrose, the latter an RAF liaison officer - is later rendered null and void, with Hollis sacrificing his life whilst steering a damaged bomber away from the village close to the base (Shepley). ${ }^{37}$ The overall impact of the American presence was thus carefully qualified: they came, they served, they sacrificed, and then they departed. Indeed, the fact that they would come but then go had already been implied at the film's beginning, which imagines Halfpenny Field many years later, now deserted, derelict and returned to England and to agriculture (a conceit also later employed in the opening scenes of Twelve O'Clock High [1949], directed by Henry King). Elsewhere, the film's other romance between Penrose and Iris Winterton (Renee Asherson) - is similarly resolved in favour of British manhood. The young American pursuing Iris loses out to Penrose, an outcome he appears to have expected: contemplating a dance to which he plans to take Iris he wonders aloud to Hollis whether she'll 'turn out to be in love with an Englishman, like all the rest'.

In plot, The Way to the Stars (1945) obviously drew inspiration from the American military presence in Britain and the various romantic encounters it bequeathed. In doing so, Asquith's film, which perhaps 'suffered from a certain looseness in construction', nonetheless 
explored (and mediated) the 'question of Anglo-American relationships'. ${ }^{38}$ And this was a telling time for such relationships. For if $1944-45$ was the moment in which the United States military increasingly became predominant in the Grand Alliance, The Way to the Stars seems to suggest that this 'fact' was not necessarily 'final'. After all, even during D-Day - which occurred exactly a year before the film was released - Britons still occupied several key leadership roles, and the British commitment on 6 June itself was on a par with that of the United States. ${ }^{39}$ This was the evolving transatlantic context in which The Way to the Stars was made, and the story it told of the friendly invasion and of the potential for Anglo-American romance and relationships was thus informed by this moment of flux. Americans are young, energetic, and look set to become the new patriarchs (as implied by Hollis' paternal interest in young baby Peter). But British manhood - older, tired, taking comfort in tea and tradition nonetheless remains resilient, at least sufficiently to see off an American pursuit of an English rose. The very ambivalence of Asquith's film - there is no sexual or romantic Anglo-American union, despite all the affection and lingering looks - also hints at contemporary ambivalence about what will become of the alliance in the post-war period. Were the Americans now in charge and 'over here' to stay? Were they the new imperial overlords, unburdened by age and infirmity? Or was British martial masculinity still vital, and the old Empire battered but unbroken?

A month later, another production - I Live at Grosvenor Square (1945) - posed a very similar set of questions. Indeed, the film, directed by Herbert Wilcox, was purposefully made with 'an eye on each side of the Atlantic'. ${ }^{40}$ Centred on a love triangle involving Lady Patricia Fairfax ('Pat', granddaughter of the fictional Duke of Exmoor, played by Anna Neagle), Major David Bruce (a British Army paratrooper, played by Rex Harrison), and USAAF Staff Sergeant John Patterson (a B-17 air gunner, played by Dean Jagger) Wilcox's film invokes all the familiar characters and clichés of the pre-war 'British Film'. ${ }^{41}$ After initial misunderstandings, 
Pat and Sergeant Patterson fall in love, a development that in turn threatens to derail an older romance involving Major Bruce just then pursuing a seat in Parliament. All then comes to a head following a party hosted by Pat's grandfather on his Exmoor estate: Bruce realises that he has 'lost' his girl to the invading Yank (at the same time he learns he has similarly lost the election). Meanwhile, the Duke discovers that he has 'lost' his estate - once again to invading Yanks, who, as in Welcome, Mr Washington, have appropriated it as a new base. Just as a potential transatlantic argument brews our representatives of British and American masculinity compete in a demonstration of stoic nobility: Sergeant Patterson, learning that Major Bruce has long loved Pat, secures medical clearance to go back to war thereby ensuring that he cannot stand in the way. Not to be outdone, Bruce, learning that Pat still loves Patterson, arranges for them to reunite near her grandfather's Exmoor estate. With Anglo-American love now seemingly back on track, fate intervenes. Patterson, en route to a romantic reunion with Pat in a damaged B-17, heroically takes the controls just as the aircraft stalls and succeeds in steering it away from the village near the Duke's estate (just like Johnny Hollis before him). The local community is saved but Patterson and his crew are killed. This is no British 'victory', however, for as Patricia and the Duke mourn Patterson in the village church (which, of course, the latter died protecting), Major Bruce re-joins his unit and readies for the invasion of Normandy.

Like The Way to the Stars before it, I Live at Grosvenor Square thus hints at contemporary perceptions of the American 'invasion'. For whilst both films conclude with the demise of American suitors both also still see representatives of the British establishment (the officer class) accept the reality of the American arrival. The latter film acknowledged an AngloAmerican parity of 'power' with regard to the hand and heart of Lady Patricia whilst also negotiating the 'problem' potentially offered by fears of American predominance by ensuring that the Briton was left to secure the final victory. That all of this unfolded within the very sort of space that had long been a preserve of Anglo-American romance - the estates of the landed 
aristocracy - was likewise important. In the 1890s, such estates had similarly seen an American 'arrival', but of a sort that did not threaten contemporary ideas of British power (wealthy American heiresses wedded to British aristocrats). ${ }^{42}$ But with an American Sergeant pursuing the daughter of a Duke, there could clearly be no ultimate love match, for such a relationship would be rather too 'special' in the demands it placed on 1940s notions of class and gender. One reviewer noted as much, suggesting it was 'a pity that the middle class sergeant from Arizona has to fall in love with an aristocrat whose home and background are almost as unlike those of most English people as the average American's'. ${ }^{43}$

Crucially, as Asquith and Wilcox explored these questions of Anglo-American relations so too did Winston Churchill. For not unlike the resilience shown by Penrose and Bruce this son of an Anglo-American love match similarly hoped there was still sufficient strength in the old Empire to allow it to stand shoulder to shoulder with the United States. In essence, this was the premise behind the very discursive framework he was just then cultivating: the 'special relationship', an idea which attempted to secure for Britain a post-war role based upon its wartime record, the still substantive Empire, and the country's historical, cultural (and, for Churchill, racial and familial) connections to the United States. ${ }^{44}$ Moreover, Churchill committed to this project with all the ardour of a lover. For as he acknowledged once the war was done, when it came to his relationship with FDR 'No man ever wooed a woman as I wooed that man for England's sake'. ${ }^{45}$ Presidential historian Michael Beschloss has gone so far as to suggest that with regard to Anglo-American diplomacy, 'Churchill pursued this as a courtship. He knew that if there was this relationship, almost like lovers, that Roosevelt might be encouraged to take a couple of chances in helping Britain. ${ }^{46}$ One of those who attended the August 1941 meeting between Churchill and FDR at Placentia Bay - John Martin, Churchill's secretary - even recorded that from his vantage point the Anglo-American ceremony which took place on the deck of HMS Prince of Wales after the talks had finished looked rather like 
'a sort of marriage service'. ${ }^{47}$ This was an idea that Churchill himself later took up, telling the King on return from the Arcadia Conference in January 1942 that 'after months of "walking out" together, Britain and America were now "married"., 48

Courtship, marriage, wooing: such was the language employed at the very highest levels of Anglo-American diplomacy as Churchill built his 'special relationship'. Little wonder that he was nonplussed - if not actively supportive - of the American affairs of his daughterin-law, Pamela. ${ }^{49}$ Little wonder, too, that ideas of Anglo-American romance and courtship duly filtered into films like The Way to the Stars (1945) and I Live at Grosvenor Square (1945). ${ }^{50}$ At the same time, something was also different in these films. Churchill's wooing clearly assumed Britain was the suitor and the United States - or FDR - the future betrothed. Indeed, after the US was attacked at Pearl Harbor, Churchill went one step further, mischievously telling his aides that 'now she [the US] is in the harem, we talk to her quite differently'. ${ }^{51}$ Yet had his 'betrothed' really joined a British 'harem'? After all, the films noted above suggested almost the exact opposite, making British womanhood the target of acquisitive Americans. The exception that proves the rule and the one post-war feature that succeeded in delivering a rather more Churchillian vision of the Atlantic Alliance, was A Matter of Life and Death (1946).

Directed by Powell and Pressburger (familiar from A Canterbury Tale), and released in November 1946 (just eight months after Churchill took to the podium in Fulton, Missouri, to call for a 'special relationship'), this film again told the story of an Anglo-American love affair, but in a manner which implied that British manhood remained not just resilient, but even 'potent'. ${ }^{52}$ The film sees David Niven in the role of Peter Carter, an RAF pilot who bails out of a damaged Lancaster after a mission over Germany, but not before establishing contact with the alluring voice of an American radio operator - June (Kim Hunter). Enter the rather mystical - and typically Powell and Pressburger - element of the film, described at the time as a 'stratospheric joke'. ${ }^{53}$ For Carter had no parachute when he jumped out of his damaged aircraft 
and so should, by rights, have died. But his 'conductor' to the Afterworld misses him due to thick fog, leaving a confused Carter to wake up in something of a limbo. 'Conductor 71' duly appears in order to explain the situation, requesting that Carter accept his death. However Carter's commitment to the present has changed - he has fallen in love with June. A trial follows: Carter is put before a heavenly jury and must make his case. The prosecutor is an American of the Revolutionary generation who hates the British and who enlists a similarly anti-British jury. Carter's trial for his life thus becomes a trial over his love for June - does he have the right to capture the heart of an American? Cue robust argument between prosecution and defence over British history and the British record. The film then climaxes with a test: does June really love Carter? And if so, what is she prepared to do? In the end, June proves her commitment (by being willing to offer her own life in Carter's stead), Carter is acquitted, and defence counsel happily declares 'nothing is stronger than love'.

Where in The Way to the Stars Penrose could find the courage to win Iris from an American suitor, Carter now similarly retains sufficient vigour to secure the hand of June. In the context of the recent friendly invasion this is still more impressive. After four years of complaints regarding the 'oversexed' American 'conquest' of British women, Carter has turned the tables. His very Britishness makes him an object of affection for an American woman 'over here'. The gendered tropes are overturned, and the power and potency of British masculinity reaffirmed. The still lingering resilience of British power is also implied by the choices actively made by both Iris and June. Both have American 'options', especially June, whose commitment to Carter thus implies a future commitment to Britain and to British citizenship (given contemporary conventions about to whom brides and betrothed 'belonged'). Yet, regardless, both choose Blighty. As would become the norm in the British war film of the 1950s, A Matter of Life and Death gave no hint of contemporary 'decline' asserting instead that the British martial male remained both resilient and resolute. ${ }^{54}$ 


\section{Americanisation: The Occupation during the Cold War, 1956-1964}

Carter and June's Anglo-American love affair was more than suggestive of contemporary Churchillian efforts to cultivate a 'special relationship' with the United States. In both instances a history of past differences had to be overlooked in favour of 'love' in the present, whilst Carter and Churchill sought to highlight transatlantic examples of common values. For Carter, American commitment to trial by jury (bequeathed by English Common Law) proved his saviour, even if the deciding factor was of course June's universe-defying commitment to him. For Churchill, meanwhile, a similar willingness to revisit Anglo-American history with reference to contemporary demands was apparent in his various post-war publications, especially The Second World War (1954), and A History of the English-Speaking Peoples (1956-58). In the latter, for example, Churchill wasted no time in drawing the Americans into his narrative (they arrive in Volume II, 'The New World'), whilst his account of the American Revolution presents it as a regrettable episode of transatlantic discord quickly overtaken by the discovery of an essential unity of purpose. ${ }^{55}$ As Churchill offered this history he was of course well aware that such an idea was just then encountering real trouble. Already by the early 1950s, Cold War concerns, American commitment to the reconstruction of former enemies (Germany and Japan), as well as British economic and imperial troubles all combined to undermine Anglo-American relations. And then came the Suez Crisis, which saw British imperial power crushingly humiliated by the American insistence that the invasion of the canal zone (conducted with French and Israeli support, but without consulting Washington) be stopped and that the troops come home. British protests against such a withdrawal were firmly met, with an old wartime ally, President Eisenhower, making clear that the operation breached 
internationally accepted norms. Shocked, and with his domestic support foundering, Prime Minister Anthony Eden (who had known Eisenhower since the 1940s) resigned. ${ }^{56}$

In the immediate aftermath of the crisis, British diplomats launched a sustained effort to re-establish the 'special relationship', and by the early 1960s it had paid some dividends. Indeed, Prime Minister Harold Macmillan and President John F. Kennedy established a close rapport, becoming perhaps the first Anglo-American leaders to do so since the age of Churchill and FDR (it surely helped that they had a family connection, and that JFK was a self-confessed Churchill fan). As the decade continued, however, with JFK dead and with the United States embroiled in a conflict that perplexed European allies - the war in Vietnam - the AngloAmerican relationship again became strained. Despite American pleas, Prime Minister Harold Wilson steadfastly refused to offer British military support in south-east Asia, whilst Britons themselves increasingly expressed their frustrations regarding American foreign policy in street protests. In 1968, a large anti-Vietnam war protest gathered outside the US Embassy in London (located, of course, at none other than Grosvenor Square). As Anglo-American foreign policies drifted further apart complaints also developed regarding the continued American military presence in Britain itself. By the end of the decade, some Britons - much like counterparts on the continent - were angrily complaining about the encroachments and corruptions of 'Americanization'. ${ }^{57}$

Such a moment produced rather different visions of the wartime friendly invasion. In 1956, for instance, the very year that the Suez Crisis broke, the Anglo-American production D-Day: Sixth of June (based on a novel by Lionel Shapiro) revisited the plot of I live at Grosvenor Square but, tellingly, reversed (in part) the conclusion. ${ }^{58}$ Where the latter had acknowledged the reality of American power whilst nonetheless ensuring it was 'gone' at the end, this 1956 production was far less sure of itself. To be sure, it still attempted to offer a vision of continued British vigour, as seen in Captain John Wynter (played by Richard Todd). 
Yet in the pursuit of his long-time sweetheart, Valerie Russell (another daughter of the aristocracy, played by Dana Wynter), Captain Wynter often seemed rather out-matched by his American rival, Captain Brad Parker (Richard Taylor). And although there was again no happy Anglo-American union at the close, this time it was nonetheless the Briton who was blown to pieces: after successfully completing his mission (leading an Anglo-American commando force in which Parker is, of course, his immediate subordinate) Wynter goes for a wander along the beach, steps on a mine, and exits the love triangle. After learning the sad news, Russell visits an injured Parker in hospital, and not unlike June in A Matter of Life and Death before her lies an opportunity to express her love for Parker. But Russell demurs, and after Parker makes clear that he will not stand between her and Wynter (believing the latter is still alive), he is loaded into an ambulance to be repatriated. Russell, forlornly, looks on as the vehicle drives off.

If D-Day: Sixth of June hinted at the shifting power dynamics implicit within the contemporary Anglo-American special relationship then two films of the 1960s were far more forceful in their suggestion of where the power now lay: War Lover (1962) and The Americanization of Emily (1964). The former was an adaptation of a John Hersey novel of the same name, published in 1959, and it tells the story of a USAAF Bomb Group based in rural East Anglia. ${ }^{59}$ At the film's centre is the story of Captain Buzz Rickson (Steve McQueen). Buzz is an aggressive bomber pilot who leads by example and who goes into combat with relish. He enjoys 'his work', and he delights in knowing that he and his comrades are the 'most destructive group of men in the world'. There was plenty here that was already familiar in Clark Gable's ambitious General in Command Decision (1948) or in Gregory Peck's similarly forceful warrior in Twelve O'Clock High (1949). ${ }^{60}$ But where these earlier films eschewed even peripheral engagement with the broader history of Americans 'over here' (being more interested in the purpose and effectiveness of strategic bombing as doctrine), War Lover takes 
Buzz into battle and then, once returned, takes him to the bar. The result is yet more destruction. For Buzz is no Peck-like hero; he is essentially a psychopath - devoid of empathy, delighting in combat and carnage, even appearing to 'climax' when he drops his 'load'. And given that he sexualises destruction and eroticises flight and fighting, once back on the ground he also unsurprisingly - pursues women with similar violence. In short, Buzz is a day-time combat pilot and a night-time rapist, with German cities and British women both victims of his peculiar brand of amoral masculinity. After one successful mission, for instance, he and his crew retire to a local pub, where he duly instigates the sexual assault of a young barmaid.

But Buzz - or at least the narrative - does have a conscience, or rather two. One is his navigator, Lynch, who he routinely belittles, but who nonetheless offers a very different brand of moral leadership. It is Lynch who intervenes in the local pub, demanding that his comrades stop their assault on the barmaid. The other is Buzz's co-pilot, Ed Boland (Robert Wagner), a figure very different in character and temperament. When it comes to flying, Boland likes to do things 'by the book', but he still recognises the worth and value of Buzz's often unconventional combat leadership (he thinks it has kept him and the crew safe). Nevertheless, the two are destined for disagreement and the cause is a British woman, Daphne Caldwell (Shirley Anne Field). Boland, long mocked by Buzz for being a puritan (he maintains he is in love with a girl 'back home'), falls for Daphne first and they embark upon a courtship. Always in the background though is Buzz, who Daphne identifies as exerting considerable power over Boland, even to the extent that she wonders if he hero worships him (he does). In time though, Boland and Buzz argue. First over the latter's conduct, then over Daphne. It is at this point that Buzz decides to assert his dominance over all - Boland and Daphne - through an act of sexual violence. Having made clear to Boland that he intends to 'compete' for Daphne (who acknowledges that Buzz is 'attractive', but 'dangerous'), Buzz pursues her, and attempts to rape her; Daphne, having defied him, then seizes the opportunity to 'target' his fundamental 
flaw, telling Buzz that 'you can't make love: you can only make hate'. Chastened and angry, Buzz departs. He later attempts something in the way of redemption by attempting to nurse a badly damaged B-17 home having already ordered all other crew - Boland included - to bail out. But he is killed instantly when the aircraft crashes into the Kent cliffs. When Bolland later informs Daphne during a stroll in Cambridge she can only reply - in recognition of the violence at the centre of Buzz's being - that 'It's what he always wanted'.

This is a very different 'invasion' to that offered by A Canterbury Tale (1944) or by The Way to the Stars (1945). In War Lover (1962), British women are 'targets' - if not chattel - and Buzz conducts himself in the manner of a conqueror or coloniser. ${ }^{61}$ Even Boland hints at this understanding of the locals: towards the start of the film he reminds Buzz that regulations forbid them from 'fraternising with the natives'. Tellingly, by exploring the relationship between Briton and American as akin to that between the 'colonised' and 'coloniser' the film bears comparison with another, connected, genre. For in the long history of attempts within French cinema to 'remember' the experience of German occupation the actions and conduct of Buzz become far more familiar. ${ }^{62}$ As such, War Lover (1962), whilst certainly both 'curious' and 'unbalanced' in structure, nonetheless exposes and explores the extent to which the friendly invasion was just that, an occupation. ${ }^{63}$ The American military is dominant, American men in charge. British masculinity is entirely absent of agency, and British women are possessions to be controlled and conquered as whim dictates. The options before the latter, suggested by the actions of the two male leads, are apparently thus to accept American 'romance' (Boland) or potentially encounter American rape (Buzz); Daphne, of course, is subject to both. Such a set of male-female relationships is suggestive of how the 1940s American military 'presence' was in actual fact experienced by some at the time. The implied sexual violence at the heart of The War Lover (1962) was not simply a retrospective imposition; it was a part of the American occupation of Britain, just as it was similarly a fundamental feature of the story of European 
'liberation'. ${ }^{64}$ At the same time, The War Lover (1962) is also powerfully suggestive of what the American military was just then becoming beyond Europe. Indeed, it anticipates the plot and politics of the 'Vietnam' war film before the conflict in South-East Asia has even properly happened (in American terms). In The War Lover, in short, the American military is an agent of colonisation and this in turn means dispossession, exploitation, and ultimately 'Americanisation'.

As the very title suggests, a similar take on the friendly invasion is apparent in The Americanization of Emily, directed by Arthur Hiller. Once again inspired by a 1959 novel (of the same name) written by US Navy officer William Bradford Huie, the film tells the story of Lieutenant Commander Charlie Madison, an American 'dog robber' - that is, aide, servant, and fixer for a senior officer - at work in London in the months before D-Day. ${ }^{65}$ Madison's superior, Rear Admiral William Jessup (Melvyn Douglas, in a role similar to 'Buck Turgidson' in Dr Strangelove [1962]) is concerned that in the upcoming invasion of Normandy the role of the Navy will be overshadowed by that of the US Army and Air Force, so he hits on a scheme to secure rightful recognition. He demands that 'the first man dead on Omaha Beach must be a sailor' and that Madison must be there with camera crew in tow to capture the moment. But there is a problem: Madison is a self-confessed coward who wants nothing to do with the invasion. Very reluctantly, and after trying to avoid his duty, Madison thus sets sail for the invasion, but on landing in Normandy he is shot by a fellow American for attempting to retreat, and then is caught up in the explosion of a German artillery shell. Assumed dead, Madison is made into the hero Jessup demanded, until he is later discovered alive and well in a Southampton hospital. At this point Madison encounters the dilemma at the heart of the film (a dilemma rather familiar to readers of Catch-22, published by Joseph Heller three years earlier, and adapted as a film in 1970): should he find the courage to admit his behaviour and accept the punishment that will surely follow? ${ }^{66}$ Or, as his English girlfriend Emily Barham 
(Julie Andrews) argues, should he accept his cowardice - in the face of fire and in the face of principle - and instead keep quiet, be the hero that Jessup wants, and thus secure happiness and a future with Emily. Such is the extent by this point of Emily's 'Americanisation'. At the start of the film, Emily, who has lost all the men in her life to the war - husband, father, and brother - is appalled by Madison's behaviour, which she sees as antithetical to her sense of England and Englishness. Nonetheless, in time, she falls in love with him; she is Americanised, but she embraces it, not wanting to lose another of the men in her life. Here, therefore, to be Americanised is to be seduced, possessed and compromised, but potentially also to be happy. Such ideas were clearly ahead of their time, however, and the film - which many contemporaries in fact saw as rather 'old fashioned' - passed with little fanfare. That said, at least one reviewer thought it succeeded in getting 'off some of the wildest, brashest and funniest situations and cracks at the lunacy of warfare that have appeared on the screen in quite some time.' ${ }^{67}$

\section{A Good War? Nostalgia, Absence and Omission, c.1979-1996}

If 1960s era films depicted the friendly invasion as an act of conquest and colonisation, by the end of the 1970s attitudes had again shifted. For instance, Hanover Street (1979), a film of 'painstaking, overripe foolishness', revisited the well-known trope of an Anglo-American love triangle, this time starring Harrison Ford as American pilot, David Holleran, and Lesley Anne Down as Margaret Sellinger, a British nurse. ${ }^{68}$ Holleran and Sellinger first meet in London shortly before a German air raid. What follows is a passionate if essentially silly romance full of 'export only' visions of 'tea-drinking rituals' and 'colourful cockneys' - with Sellinger declaring her love for Holleran even though she is married ${ }^{69}$ Her husband, a British Intelligence 
Officer, Paul Sellinger, played by Christopher Plummer, remains unware of the affair throughout, although he is conscious of being unworthy of Margaret's love - he is, he believes, nothing more than 'pleasant'. As the subgenre demands, this love triangle is ultimately brought to crisis with a sequence of less than plausible coincidences. Holleran, deeply in love with Margaret, becomes increasingly cautious as a pilot, even to the extent that he 'imagines' an engine problem which leads him to withdraw from a dangerous mission whilst his aircraft is still on the tarmac. As punishment for this act of perceived cowardice, the base commander assigns him to a secretive special mission, which turns out to be dropping a British agent - Paul - into France so that he can recover an important file from the Gestapo. But Holleran's plane is badly damaged by flak and his crew killed; he bails out with Paul, and must join forces with him to complete the mission. At this point, the conventions of the subgenre are flouted. Usually, the Briton is wise and experienced whilst the American is naïve and bold. The film does retain some of this - Holleran, like Ford's more famous pilot character, Hans Solo - meets danger with dash. Yet Paul, whilst undoubtedly brave, is nevertheless revealed as a novice. Holleran thus emerges as both the brawn and brains of the operation, going so far as to save Paul from death all the while in the knowledge that to do so is to ensure the end of his own romance with Margaret. The result is that Paul's marriage survives and her family remains 'intact' (she and Paul have a daughter, played by a young Patsy Kensit); but this is the result of American largess, and of American sacrifice. ${ }^{70}$

Yanks (1979), released in the very same year, offered a rather harsher take on the friendly invasion. Set in the months before D-Day and starring another young actor later to make a name in Hollywood - Richard Gere - the film tells the story of the American occupation as experienced not, in this instance, near a bomber base in eastern England but, rather, in a wet and war-weary Lancashire town. A personal project of director John Scheslinger, Yanks (like Hanover Street) recycles what had by now become the generic conventions, with one reviewer 
noting that the result was an 'entertaining and sentimental' yet ultimately 'old fashioned romance'. ${ }^{71}$ At the film's centre is the story of Sergeant Matt Dyson (Gere) and Jean Moreton (Lisa Eichorn), who meet when the former, newly arrived, is on leave in a local town. Jean is already engaged to Ken, a British soldier serving overseas, and initially she rebuffs Dyson's advances (like Patricia Fairfax in I Live at Grosvenor Square or Valerie Russell in D-Day: Sixth of June). In time though, Jean mellows and a largely platonic relationship develops (with shades of Toddy and Hollis in The Way to the Stars), before it then becomes a romance, notwithstanding the 'return' of Ken. The latter is only briefly on leave though and soon away to the war, where the 'problem' he offers to the plot is suitably dealt with, again in time honoured fashion: like John Wynter before him Ken dies in combat, leaving the field clear for Dyson. However, a subsequent romantic retreat on the Welsh coast - undertaken despite Jean's mother declaring it to be a betrayal of Ken - only leads to hurt and heartache, with Jean fearful that Dyson does not in fact love her for he feels unable to consummate the union. War then intervenes, with D-Day again offering a familiar obstacle to a successful Anglo-American love union. Dyson and comrades are loaded onto trains headed to the south coast in readiness for the Normandy invasion, but not before a tearful Jean stands at the station waving to Dyson, who shouts through the noise that he will 'return'. Meanwhile, another relationship also blooms in the background, this time of a more familiar sort in the sense that it involves an American officer and a daughter of the British gentry. Captain John (William Devane) and Helen (Vanessa Redgrave) meet frequently at the latter's manor house, finding a closeness which is in part a product of what both lacks. Helen's husband is in the Navy and away at sea; John's wife is similarly distant. Unlike Matt and Jean, their relationship is consummated, but like Holleran and Margaret Sellinger it cannot last; John departs for the war in France, whilst Helen's husband returns on leave. ${ }^{72}$ 
Much like Hanover Street, therefore, Yanks did not offer the sort of clear resolution frequently implied in the subgenre, but rarely realised. For whilst another of the film's AngloAmerican relationships - between the best friends of Matt and Jean - is consummated (with marriage and pregnancy), the story at the centre of the plot produces no publicly recognised 'union'. If, in this sense, both 1979 productions were very much in tune with the established conventions, they did nonetheless provide something of a new departure in terms of overall tone and tenor: we are a long way here from the sexual violence of The War Lover or from the conquest (and colonisation) of The Americanization of Emily. Instead, like other war-themed productions of this era, both films are essentially nostalgic, fondly romanticising the time when 'our Yanks' were 'over here', with the latter event now seen through rose-tinted spectacles. Hence the importance of Dyson declaring that he will 'return'; in 1979, when the film was released, American veterans of the Second World War had indeed started to return to Britain for emotional reunions with old friends and lovers, and for nostalgic pilgrimages to old bases. By the 1980s, such visits had become an annual occurrence, and would remain so right through until the end of the 1990s. ${ }^{73}$ In 1992, tourist authorities in Eastern England even organised a whole itinerary of nostalgic events and activities linked to the 'return' of thousands of US veterans to their old air bases.

In such nostalgia, Hanover Street and Yanks also anticipated a key trend in Second World War-themed film and television across much of the 1980s and 1990s. In the United States, this was the era in which the cultural and political 'trauma' of Vietnam encouraged many to look with new interest at the far more reassuring national record in the 1940s, a project which found in President Ronald Reagan a highly effective champion. In 1984, for example, Reagan (a former actor in wartime propaganda films) stood on the cliff-tops overlooking the D-Day beaches to offer a powerfully appealing vision of the Second World War as an era of national unity, patriotic duty, and victory (all in stark contrast to the experience of Vietnam). ${ }^{74}$ 
The same year, historian Studs Terkel succinctly identified what was clearly then emerging: the idea that the 1940s battle with Nazism was nothing less than a 'Good War'. ${ }^{75}$ The end of the Cold War in 1989-90, victory in the Gulf War (1991), and the renewed interest of Hollywood (as seen in the success of Saving Private Ryan [1998]) duly ensured that the Second World War gained still greater visibility and currency. By the end of the 1990s, a spate of fiftieth anniversary commemorations ensured that on both sides of the Atlantic there was a 'renewed public interest in dramatic representations of the war in both film and television'. ${ }^{76}$

In Britain meanwhile, contemporary events similarly rejuvenated collective interest in images and ideas from the 1940s, with the Falklands War of 1982 providing a global stage for the British public and politicians to demonstrate their Churchillian fortitude. Indeed, the British press purposefully cultivated analogies between present endeavours and key events from the Second World War. Thus, the departure of the British Task Force from Portsmouth had a certain 'little ships' of Dunkirk quality, the air battle waged over the Islands by the pilots of the Royal Navy was reported with more than a hint of 'The Few', and the landing of British troops at San Carlos Bay 'went in exactly according to the D-Day model'. ${ }^{77}$ Elsewhere, the fact that Prime Minister Margaret Thatcher had managed to secure ultimate American backing seemed to suggest that the 'special relationship' was alive and well, and that the 'Yanks' were still very much with us. At times, the closeness of the ideological connection between the prime minister and her ex-Hollywood counterpart in Washington was itself romanticised. In 1981, for instance, the Socialist Workers Party produced a widely disseminated poster depicting Thatcher swooning in Reagan's arms (à la Gone with the Wind) whilst the mushroom clouds of Armageddon billow in the background. ${ }^{78}$ Throughout her time in office, Thatcher continued to affirm in word and action her commitment to this 'special relationship', even if popular attitudes in Britain at times became more hostile to the American ally. By the mid-1980s, for 
example, there was an increasingly large protest gathering at the American base at Greenham Common, especially following the arrival of American cruise missiles in $1984 .{ }^{79}$

Any emerging British resentment over the contemporary US military presence was largely ignored, however, in the vision of the friendly invasion filmed in 1981 and aired on ITV in 1982: We'll Meet Again, made by LWT, ran between February and May (just as British forces battled to retake the Falkland Islands). This was the first sustained televisual attempt to examine the wartime friendly invasion, save for the Twentieth Century Fox series Twelve O'Clock High (1964-1967) which was ultimately cancelled during its third season. ${ }^{80}$ Where this earlier series often focused on questions of bombing strategy and doctrine, We'll Meet Again, following a shift in the Second World War drama that had first developed in the 1970s, turns attention to private lives, love and romance. ${ }^{81}$ One reviewer suggested that the series represented an 'unashamed return to romance and nostalgia', whilst the script editor, David Crane, explained why, noting that life in 1943 'called for simple virtues and simple strengths' ${ }^{82}$

Telling the story of an American bomber base in Suffolk, the series begins with scenes of brash Americans driving jeeps through a quiet village, as usual pursuing local girls. British men look on with distrust and disdain, with one in particular rehearsing all the familiar clichés about the Yanks being late and over-bearing. At times, the extent to which the American presence was akin to an occupation also features prominently, something accentuated by the fact that LWT had only recently produced another series exploring this subject: Enemy at the Door (1978-1980) told the story of the German occupation of the Channel Islands. The father most hostile to the invading Yanks in We'll Meet Again is even a repeat of a character from this earlier production (played by the very same actor). Over the subsequent twelve episodes all the usual Anglo-American romantic liaisons are examined. One local girl becomes pregnant by a GI. Another 'falls' for the American who saves her from a marauding German fighter plane (which, conveniently, also removes from the picture the young British soldier who was 
sweet on her); they wed before the end. Another develops a somewhat platonic relationship with a widowed mother (à la Johnny Hollis and Toddy in The Way to the Stars). And the lady of the local manor, Dr Helen Dereham, played by Susannah York, is courted by the base commander, Major James Kiley (Michael Shannon) whilst her husband is away to the war. This latter scenario is of course potentially problematic to the Anglo-American alliance, and so, as the subgenre dictates, there is no 'union' at the end. Instead, and like Yanks before it, Major Wiley, bidding farewell with the war almost done tells a teary-eyed Helen 'we'll meet again'. The show proved a success with audiences, with historian Mark Connelly noting that it 'hit all the buttons of popular memory'. ${ }^{83}$ The ratings certainly seem to agree, with the series securing 14.95 million viewers in March 1982 (19th in the top 50), dropping slightly to 13.65 million in May 1982 (which nonetheless pushed it to 12th in the top 50). ${ }^{84}$

For all its success, the 'return to romance and nostalgia' offered by We'll Meet Again also now exposed a glaring absence, one which had actually been structural to the subgenre since the war. For as convention dictated, the series avoided any acknowledgment of the fact that the wartime American presence - in Suffolk and elsewhere - included several thousand African American personnel, all of whom served in segregated units: by 1944 there were 130,000 African American service-personnel in the whole of the UK, of which around 12,000 were in eastern England. ${ }^{85}$ This fact had long been marginalised. ${ }^{86}$ For instance, whilst Welcome to Britain briefly acknowledged the contributions of black servicemen, it did so in a manner which simultaneously made clear towards whom the documentary was really directed: white GIs. The scene in question involves Burgess Meredith witnessing a conversation between a black GI and an elderly British woman, before turning to camera to explain that 'there are less social restrictions in this country'. Meredith then joins an American officer - carefully identified as General Lee, head of the Services of Supply, and of Confederate ancestry - who, in a display of consummate racial paternalism, remarks that 'America has promised the Negro 
real citizenship and a fair chance to make the best of himself'. A speech follows, with Meredith interjecting at one point to ask whether 'you mean that we have to get over our prejudices'; the General responds with a knowing smile, suggesting that 'you don't get over a prejudice that easily' but that 'we can try to live up to our American promises'. The scene closes with shots of Meredith and the unnamed black GI saluting the General, and then sharing a cigarette.

If Welcome to Britain acknowledged and then instantly dismissed the African American presence, many contemporary publications failed to do even this. Meanwhile, the British government, keen to avoid any official confrontation, accommodated the US Military's policy of segregation. ${ }^{87}$ The result was that towns "near American bases were "black" one night and "white" the next'. ${ }^{88}$ Evidence makes clear that the British reception was mixed: some people certainly criticised the 'colour bar' and welcomed African American troops with warmth and kindness. Elsewhere, local attitudes could, on occasion, be just as racist as those of white servicemen from the Deep South. Such complexities of response perhaps help explain why most filmic treatments of the friendly invasion have avoided exploring the presence in Britain of black American service-personnel. Thus, from A Canterbury Tale to The Way to the Stars, to The War Lover and Hanover Street, whilst films exploring the friendly invasion persistently interrogated the gendered complexities of Anglo-American relations, they studiously ignored the equally complex question of transatlantic race-relations. ${ }^{89}$

The one exception was Yanks, which included a harrowing scene at a dance hall in which white GIs, incensed by the sight of black counterparts dancing with local women, embark upon an orgy of violence, almost leading to the lynching of one black soldier. Outraged by what they see, and after order is restored, several local women - led by Jean - then purposefully dance with the remaining black GIs, publicly demonstrating their disregard for the American 'colour bar'. Later, having retired to a nearby bar, Jean takes Matt - an Arizonan, thus neither 'northern' nor 'southern' - to task for his moral cowardice in the face of racist 
violence. Matt's defence acknowledges what he understands to be the 'reality'. As he tells Jean: 'A black guy, and a white girl. He knew the score'. He then proceeds to explain to Jean that for all their mutual love, they - and, by implication, their two countries - are different: 'we talk the same, look the same, but ain't the same'. Jean responds that he could nonetheless 'try' to be different and 'try' to be what she expects, at least with regard to her measures of moral conduct and courage. But a decade after Enoch Powell's infamous 'Rivers of Blood' speech and just two years before the Brixton Riots, the result is a rather self-congratulatory tone in which British capacity for racial intolerance is displaced onto segregationist southerners, whilst the black GI characters themselves are peripheral to the narrative throughout. We do not learn what becomes of the GI almost lynched; we do not even learn his name. ${ }^{90}$

When seen in the broader context of the genre even such displacement and disregard is something of an improvement on the far more familiar omission of the wartime African American presence entirely. It was not until 1995 that this presence was fully examined in popular culture. The examination in question - The Affair, directed by a Briton, Paul Seed followed the story of a platoon of black GIs stationed in rural England and subject to racist abuse at the hands of their white 'comrades', often due (as in Yanks) to the latter's intolerance of inter-racial, Anglo-American, relationships. At the centre of the story is the romance between one particular black GI - Travis Holloway (played by Courtney B. Vance) - and a local woman, Maggie Leyland (played by Kerry Fox). As convention dictates, Maggie is married and like Helen in Yanks her husband, Edward Leyland, is away in the Navy. At first, therefore, she and Travis avoid a relationship, but eventually they become lovers. Their romance is then interrupted by the return of Edward, who, discovering Maggie and Travis making love, has the latter arrested for rape. Maggie, stunned and confused, goes along with this, but later tries to change her statement when she realises that Travis faces capital punishment. Her efforts are thwarted by Edward and by Travis's racist commanding officer 
(and judge at his court martial). Travis learns of Maggie's attempts to make amends, but is hanged regardless; Maggie is informed by letter of his death, and is crushed.

Such a powerful and poignant treatment of the politically charged issue of wartime inter-racial Anglo-American romance was partly a product of contemporary historiographical developments. Neil Wynn's pioneering 1976 history, The Afro-American and the Second World War (with a second edition in 1993, just two years before the film was released) provided the first full historical account of the African American experience of the conflict at home and abroad. This was followed in 1987 by Graham Smith's equally revealing history of the presence in 1940s Britain of black service-personnel, When Jim Crow Met John Bull, as well as by the extensive treatment given to race relations in David Reynolds' 1995 history, Rich Relations. Notably, these histories drew particular attention to the inequities of wartime military law and especially the fact that African American service personnel were disproportionately represented in the military judicial process. The Affair (1995), together with another film released in the very same year - The Tuskegee Airmen (1995) - was thus part of a late twentieth century effort to confront some of those issues long overlooked, if not actively omitted, from the cultural memory of the Second World War. ${ }^{91}$

Even so, The Affair remains something of an outlier, with similar issues only very occasionally broached elsewhere. Just a few years earlier, for instance, the successful David Putnam production Memphis Belle (1990) - a fictional remake of William Wyler's 1944 documentary (with his daughter, Catherine, as producer) - adhered to convention and avoided discussion of race. It even omitted any attempt to explore the far more familiar issue of AngloAmerican love or romance, save for a very brief fling between an English girl - 'Faith' (Jane Horrocks) and an American, 'Virgil' (Reed Diamond). It was not always to be so. Early scripts reveal that initially the film was to include all the usual components of a friendly invasion story: a scene at a local pub; a love triangle involving young American airmen and the daughter 
of the local gentry (the original character of 'Faith', who was to have far more screen time). But all was gone by the final cut, with the director, Michael Caton Jones, clearly intent on telling a story about (white) American men, their courage, and their war-winning weapon, the B-17 bomber. ${ }^{92}$ Six years later, an episode of the popular BBC sitcom Goodnight Sweetheart (1996) did better. Titled 'The Yanks are Coming', the episode sees American military racism confronted, although the result was again largely self-congratulatory: the time-travelling central character, Gary Sparrow, brings his racially progressive 1990s sensibilities to bear (enabling the audience to feel good about itself) whilst his 1940s beau, Phoebe, single-handily breaks the colour bar by refusing to accommodate Southern-style segregation in her pub. ${ }^{93}$ The very same year, however, usual service was resumed in another BBC production - Over Here (1996) - that again ignored the presence in Britain of African American servicemen. This two part comedy-drama starring Martin Clunes and Samuel West as RAF officers playing host to arriving Yanks (like Penrose in The Way to the Stars) had plenty of time for Anglo-American love-triangles; but much less for segregation or racial discrimination.

\section{Conclusions}

Over the past two decades, the idea that international relations operate with reference to gendered tropes and racialized assumptions has received detailed attention. ${ }^{94}$ Elsewhere, the place of the Second World War in British cultural memory, as well as the diplomatic history (and significance) of elite level male-female romantic liaisons, have likewise been the subject of focused research. Despite such interest, the specific ways in which very similar transatlantic liaisons have been represented in post-war popular culture has largely been overlooked. This is in spite of the fact that the conceptualisation of Anglo-American relations that has so shaped this culture - the 'special relationship' - is in origin and phraseology explicitly gendered. After 
all, it was coined by the child of an Anglo-American love-match; a man who, by his own admission, pursued transatlantic diplomacy as courtship. Seen in these terms, depictions of wartime Anglo-American 'courtships' become, by implication, spaces in which the very idea of the 'special relationship' is made, mediated and mythologised.

During the war itself, as Britain was invaded by hundreds of thousands of Yanks, contemporary film - such as A Canterbury Tale, The Way to the Stars, and I live at Grosvenor Square - attempted to reassure (British) audiences that this invasion did not imply a loss of British power. Hence why so few of the films from the 1940s and 1950s concluded with an Anglo-American love union, or indeed with the Yank still standing. Some, such as A Matter of Life and Death, even suggested - like other films of the post-war period - that British masculinity remained sufficiently potent to be actively attractive to American women. By the 1960s, such filmic demonstrations of continued British resilience had largely disappeared. The friendly invasion films of this era - like The War Lover and The Americanization of Emilytold stories that conflated American military power with American sexual potency. These productions had plenty to say about the idea of the wartime American presence as an 'invasion', but they said far less about it being 'friendly'. This was invasion as Americanisation, and Americanisation as colonisation.

In the 1980s, as Anglo-American diplomatic relations found a new closeness in the ideological (and occasionally romanticised) connections between Margaret Thatcher and Ronald Reagan, and just as the Second World War took on an increasingly nostalgic aura, the American invasion was again 'repictured'. Stories of romance and of unrequited love came to the fore as memories of the brash young Americans of history were now seen through the sepia tones of distant - and depoliticised - memory. This was the era in which thousands of Yanks, now aged and infirm, made journeys back to their old English bases to meet with old English friends. But such nostalgia also had other, problematic, consequences. There was little space 
here for engaged exploration of one key feature of the friendly invasion that the subgenre - for such it now was - had always overlooked: the presence of segregated African American personnel. Aside from The Affair, this subject, and all that goes with it in terms of a deeper understanding of the Anglo-American relationship and of race relations in Britain, has remained marginalised. ${ }^{95}$ Exploring cultural representations of the wartime American presence in Britain thus reveals much about shifting understandings of the 'special relationship' whilst also exposing those aspects which, even now, remain largely neglected, unappreciated, and unknown.

${ }^{1}$ David Reynolds, Rich Relations: The American Occupation of Britain, 1942-1945 (London: Phoenix Press, 2000), 104.

${ }^{2}$ See Mary Beth Norton, The British-Americans: The Loyalist Exiles in England, 1774-1789 (London: Constable, 1974).

${ }^{3}$ Reynolds, Rich Relations, xxviii. Other histories of the 'invasion' and of the US presence in wartime Britain include Juliet Gardiner, Over Here: The GIs in Wartime Britain (London: Collins \& Brown, 1992); Norman Longmate, The GIs: The Americans in Britain, 1942-1945 (London: Hutchinson, 1975); Roger A. Freeman, The Friendly Invasion (Lavenham: Terence Dalton, 1992); Henry Buckton, Friendly Invasion: Memories of Operation Bolero, The American Occupation of Britain, 1942-1945 (Chichester: Phillimore, 2006).

${ }^{4}$ Reynolds, Rich Relations, xxiv.

${ }^{5}$ Sonya Rose, 'The 'Sex Question' in Anglo-American Relations in the Second World War, The International History Review, 20, no. 4 (1998), 884-903.

${ }^{6}$ Ibid. See also Reynolds, Rich Relations, 200-215; Gardiner, Over Here; John Costello, Love, Sex and War: 1939-1945 (London: Pan Books, 1985), 309-31. For the place of sex more generally in the conduct of the American military's European campaign, see Mary 
Louise Roberts, What Soldiers Do: Sex and the American GI in World War II France

(Chicago: University of Chicago Press, 2013).

${ }^{7}$ See Pamela Winfield, Sentimental Journey: The Story of the GI Brides (London: Book Club Associates, 1984); Jenel Virden, Goodbye Piccadilly: British War Brides in America

(Urbana: University of Illinois Press, 1996); Susan Zeiger, Entangling Alliances: Foreign

War Brides and American Soldiers in the Twentieth Century (New York: New York

University Press, 2010).

${ }^{8}$ The cultural memory of Britain's Second World War experience has been the subject of engaged analysis. For a sense of the field, see Mark Connelly, We Can Take It! Britain and the Memory of the Second World War (London: Pearson, 2004); Lucy Noakes, War and the British: Gender, Memory and National Identity (London: I.B. Tauris, 1998); Malcolm Smith, Britain and 1940: History, Myth and Popular Memory (London: Routledge, 2000); Lucy Noakes and Juliette Pattison, British Cultural Memory and the Second World War (London: Continuum, 2013); Geoff Eley, 'Finding the People's War: Film, British Collective Memory, and World War II,' American Historical Review 106, no. 3 (2001), 818-38; John Ramsden, 'Myths and Realities of the 'People's War' in Britain,' in Jorg Echternkamp and Stefan Martens, eds, Experience and Memory: The Second World War in Europe (Oxford: Berghahn, 2010), 40-52; Penny Summerfield, 'Dunkirk and the Popular Memory of Britain at War, 194058,' Journal of Contemporary History 45, no. 4 (2010), 788-811.

${ }^{9}$ The history of Anglo-American homosexual relationships and encounters is still to be written, though connected issues are explored by Emma Vickers in Queen and Country: Same-Sex Desire in the British Armed Forces, 1939-45 (Manchester: Manchester University Press, 2013).

${ }^{10}$ Whilst the two mediums are clearly different, they often share much in terms of narrative content and by the end of the twentieth century 'films' were as likely to be watched on 
television screens as they were in the cinema. For some discussions of this, see Michael Paris, ed., Repicturing the Second World War: Representations in Film and Television (Basingstoke: Palgrave Macmillan, 2007), 7-9. 'British' film and television is here defined as any work directed by Britons, starring Britons, or made in Britain by British production companies.

${ }^{11}$ Emily S. Rosenberg, 'Foreign Affairs after World War II: Connecting Sexual and International Politics', Diplomatic History, 18 (1994), 59-70.

${ }^{12}$ Only a handful of works have specifically explored the wartime friendly invasion: Phillip Simpson, 'Yanks and Popular Memory', in Geoff Hurd, ed., National Fictions: World War II in British Films and Television (London: BFI Books, 1984), 68-72; Wendy Webster, “"Rosetinted Blighty": Gender and Genre in Land Girls', in Paris, ed., Repicturing the Second World War, esp. 24; Connelly, We Can Take It!, 186-89. See also Sue Harper, 'The Representation of Women in British Feature Films, 1939-1945', in Phillip M. Taylor, ed., Britain and the Cinema in the Second World War (Manchester: Manchester University Press, 1988), 168202. The subject of Anglo-American romantic relationships has also received sustained attention in popular fiction, especially over the last thirty years. For a sense of this genre, see Len Deighton, Goodbye Mickey Mouse (London: Grafton, 1983); Robert Radcliffe, Under an English Heaven (London: Little, Brown, 2002); Margaret Mayhew, Our Yanks (London: Corgi, 2001); Margaret Mayhew, I'll be Seeing You (London: Corgi, 2004); Eileen Ramsey, The GI Bride (London: Zaffre, 2018).

${ }^{13}$ Frank Costigliola, 'Pamela Churchill, Wartime London and the Making of the Special Relationship', Diplomatic History, 36, no.4 (2012), 753-62.

${ }^{14}$ Frank Costigliola, ' 'Unceasing Pressure for Penetration: Gender, Pathology, and Emotion in George Kennan's Formation of the Cold War', Journal of American History, 83, no. 4 (1997), 1309-39. 
${ }^{15}$ David Dimbleby and David Reynolds, An Ocean Apart: The Relationship between Britain and America in the Twentieth Century (London: Hodder and Stoughton, 1988), 150.

${ }^{16}$ Graham Smith, The Mighty Eighth in the Second World War (Newbury: Countryside Books, 2001); Donald L. Miller, Eighth Air Force: The American Bomber Crews in Britain (London: Aurum Press, 2007); Kevin Wilson, Blood and Fears: How America's Bomber Boys and Girls in England Won Their War (London: Orion, 2017).

${ }^{17}$ Reynolds, Rich Relations, 110-11.

${ }^{18}$ Instructions for American Servicemen in Britain 1942 (Washington, D.C.: War Department, 1942).

${ }^{19}$ Thomas Burke, The English and their Country: For Overseas Forces (London: British Council, 1944).

${ }^{20}$ H. Mark Glancy, When Hollywood Loved Britain: The Hollywood 'British' Film 1939-45

(Manchester: Manchester University Press, 1999).

${ }^{21}$ Glancy, When Hollywood Loved Britain, see esp. 117-122.

${ }^{22}$ For Zanuck's keen commitment to American intervention in the Second World War, see George F. Custen, Twentieth Century's Fox: Daryl F. Zanuck and the Culture of Hollywood (New York: Basic Books, 1997).

${ }^{23}$ The film was followed soon after by a novelisation. See Harlan Thomas, $A$ Yank in the RAF (London: Nicholson \& Watson, 1941).

${ }^{24}$ B. Crowther, The New York Times, September 27, 1941.

${ }^{25}$ Ibid.

${ }^{26}$ For an engaging take on the wartime collaboration between Hollywood and government, see Mark Harris, Five Came Back: A Story of Hollywood and the Second World War (Edinburgh: Cannongate, 2015). See also Clayton R. Koppes, Hollywood Goes to War: How Politics, Profits and Propaganda Shaped World War II Movies (London: Tauris, 1988); 
Thomas P. Doherty, Projections of War: Hollywood, American Culture and World War II (New York: Columbia University Press, 1999). For the role of film in the British war effort, see James Chapman, The British at War: Cinema, State and Propaganda, 1939-1945 (London: I.B. Tauris, 1998); Anthony Aldgate and Jeffrey Richards, Britain Can Take It: British Cinema in the Second World War (London: I.B. Tauris, 1994).

${ }^{27}$ Other wartime films in this vein included Air Force (1943) and Fortress (1944). Some of the footage Wyler shot for The Memphis Belle (1944) has recently been digitally restored and, with commentary and narration from surviving 8th Air Force B-17 crews, has been released as a new documentary: The Cold Blue (2018).

${ }^{28}$ See Starr Smith, Jimmy Stewart: Bomber Pilot (Minneapolis: Zenith Press, 2005).

${ }^{29}$ Senior officers in the USAAF were particularly attentive to the potential of film. See Steve Call, Selling Air Power: Military Aviation and American Popular Culture after World War II (College Station: Texas A\&M University Press, 2009). For some details about the government-sponsored 'Why We Fight' series of films, see Ian Scott, 'Why We Fight and Projections of America: Frank Capra, Robert Riskin and the Making of World War II Propaganda', in Peter C. Collins and John E. O'Connor, Why We Fought: America's Wars in Film and History (Lexington: University Press of Kentucky, 2008), 242-58.

${ }^{30}$ Lehman also starred in Fortress (1944).

${ }^{31}$ L. Collier, The Picturegoer, August 19, 1944.

${ }^{32}$ For a detailed story of the Powell and Pressburger cannon, see Andrew Moor, Powell and Pressburger: A Cinema of Magic Spaces (London: I.B. Tauris, 2012).

${ }^{33}$ See Tison Pugh, 'Perverse Pastoralism and Medieval Melancholia in Powell and Pressburger's A Canterbury Tale', Arthuriana, 19, no. 3 (2009), 101. For analysis of $A$ Canterbury Tale, see also Carl C. Curtis III, 'Powell and Pressburger's A Canterbury Tale: New Pilgrims, Old Pilgrimage', Literature and Film Quarterly, 36, no. 1 (2008), 68-77. 
${ }^{34}$ See L. Hiscott, 'Film Production Planned Encouraging Anglo-American Relations', Kinematograph Weekly, January 13, 1944.

35 'Lost' for many years, Welcome, Mr Washington (1944) was rediscovered in 2015 and then screened by the BFI in January 2016 (the first time it had been seen since airing on British television in 1961). See: https://www.bfi.org.uk/sites/bfi.org.uk/files/downloads/bfi-pressrelease-welcome-mr-washington-returns-national-archive-2016-01-14.pdf (accessed April 5, 2019).

${ }^{36}$ See The Monthly Film Bulletin, May 1944; Kinematograph Weekly, January 13, 1944.

${ }^{37}$ Such heroics were no doubt partly inspired by contemporary tragedies. In August 1944, for example, an American bomber taking off from Warton airbase near Preston failed to avoid the nearby village of Freckleton. The plane crashed into the village school, killing 61 people of whom 38 were children. See James R. Hedtke, The Freckleton, England, Air Disaster (Jefferson: McFarland, 2014).

${ }^{38}$ See The Monthly Film Bulletin, January 1, 1945, 70.

${ }^{39}$ For instance, all General Eisenhower's immediate subordinates were Britons, whilst in terms of ships committed to the operation, the Royal Navy outnumbered its American counterpart.

${ }^{40}$ Monthly Film Bulletin, June 30, 1945, 69.

${ }^{41}$ It was even released in the US as A Yank in London (1945).

${ }^{42}$ Dana Cooper, Informal Ambassadors: American Women, Transatlantic Marriages, and Anglo-American Relations, 1865-1945 (Kent, OH: Kent State University Press, 2014).

${ }^{43}$ Monthly Film Bulletin, June 30, 1945, 69.

${ }^{44}$ For origins of the phrase and idea, see David Reynolds, 'The Special Relationship': Rethinking Anglo-American Relations', International Affairs, 65, no. 1 (1988-89), 64-81. 
${ }^{45}$ Winston Churchill, quoted in Carlo D'Este, Warlord: A Life of Churchill at War, 18741945 (London: Allen Lane, 2009), 567.

${ }^{46}$ Beschloss, quoted in ibid., 568.

${ }^{47}$ John Martin, quoted in ibid., 577.

${ }^{48}$ Dimbleby and Reynolds, An Ocean Apart, 140.

${ }^{49}$ Costigliola, 'Pamela Churchill, Wartime London and the Making of the Special Relationship', 753-62.

${ }^{50}$ The ideas lingered into the 1950s. See, for instance, Appointment in London (1953), in which the plot again revolves around an Anglo-American love triangle, although this time the charisma of the British lead - played by Dirk Bogarde - is more than sufficient to see off his American rival, played by William Sylvester. For some details, see Monthly Film Bulletin, March 14, 1953, 9.

${ }^{51}$ Churchill, quoted in Dimbleby and Reynolds, An Ocean Apart, 138.

${ }^{52}$ For an extended discussion of Churchill's Fulton speech, including its impact and legacy, see Alan Dobson and Steve Marsh, eds, Churchill and the Anglo-American Special Relationship (London: Routledge, 2017).

${ }^{53}$ Monthly Film Bulletin, January 1, 1946, 148.

${ }^{54}$ See John Ramsden, 'Refocusing the 'People's War': British War Films of the 1950s', Journal of Contemporary History, 33, no. 1 (1998), 63-75.

${ }^{55}$ See especially: Winston S. Churchill, The Second World War, Volume III: The Grand Alliance (London: Cassell, 1950); Winston S. Churchill, A History of the English-Speaking Peoples, Volume II: The New World (London: Cassell, 1956), and Winston S. Churchill, $A$ History of the English-Speaking Peoples, Volume IV: The Great Democracies (London: Cassell, 1958). See also David Reynolds, In Command of History: Fighting and Writing the Second World War (London: Allen Lane, 2004). 
${ }^{56}$ For a detailed history of the Suez Crisis, see W.S. Lucas, Divided We Stand: Britain, the US and the Suez Crisis (London: Hodder and Stoughton, 1991).

${ }^{57}$ For Anglo-American relations in the 1950s and 1960s, see Richard Aldous, Macmillan, Eisenhower and the Cold War (Dublin: Four Courts Press, 2005); Catherine Hynes and Sandra Scanlon, Reform and Renewal: Transatlantic Relations during the 1960s and 1970s (Newcastle: Cambridge Scholars, 2009). For detailed discussion of Anglo-American relations and Vietnam, see Peter Busch, All the Way with Vietnam: Britain, the US, and the Vietnam War (Oxford: Oxford University Press, 2003); Sylvia Ellis, Britain, America and the Vietnam War (Westport: Greenwood Publishing, 2004). For British and European responses to ‘Americanisation' see Richard Pells, Not Like Us: How Europeans have loved, hated and transformed American culture since World War II (New York: Basic Books, 1997). 1960s era films other than those focused explicitly on the friendly invasion also explored contemporary Anglo-American relations, perhaps most notably the James Bond franchise. For some details about this, see James Chapman, License to Thrill: A Cultural History of the James Bond Films (London: I.B. Tauris, 2007).

${ }^{58}$ Lionel Shapiro, The Sixth of June (London: Collins, 1955).

${ }^{59}$ John Hersey, The War Lover (New York: Alfred J. Knopf, 1959).

${ }^{60}$ For some details about both films, see Call, Selling Air Power. For details specifically about Twelve O'Clock High see also Allan T. Duffin and Paul Matheis, The 12 O'Clock High Logbook (Boalsburg: BearManor Media, 2005).

${ }^{61}$ See Ralph Donald and Karen MacDonald, Women in War Films: From Helpless Heroine to GI Jane (London: Rowman and Littlefield, 2014), 77.

${ }^{62}$ See Leah D. Hewitt, Remembering the Occupation in French Film (Basingstoke: Palgrave Macmillan, 2008).

${ }^{63}$ Monthly Film Bulletin, January 1, 1963, 104. 
${ }^{64}$ See Roberts, What Soldiers Do. See also Robert J. Lilly, Taken by Force: Rape and American GIs in Europe during World War II (New York: Palgrave Macmillan, 2007). In 2006, the release of previously secret Home Office files detailing aspects of the American presence was even reported in The Telegraph under the headline 'Wartime GIs went on rampage of rape and murder'. See The Telegraph, April 25, 2006:

https://www.telegraph.co.uk/news/uknews/1516599/Wartime-GIs-went-on-rampage-of-rapeand-murder.html (accessed April 5, 2019).

${ }^{65}$ For the novel, see William B. Huie, The Americanization of Emily (Boston: E.P. Dutton, 1959).

${ }^{66}$ See Joseph Heller, Catch-22 (New York: Simon and Schuster, 1961).

${ }^{67}$ See Monthly Film Bulletin, January 1, 1965, 86; New York Times, October 28, 1964, 51. For further analysis of the film, see also R.A. Voeltz, 'A Pacifist and/or Cowardly Yank in Britain: The Americanization of Emily (1964) as anti-war classic', Film International, 11, no. 2 (2013), 32-43.

${ }^{68}$ New York Times, May 18, 1979, 11.

${ }^{69}$ Monthly Film Bulletin, January 1, 1979, 174.

${ }^{70}$ For The Americanization of Emily (1964) in American memory, see Michael Dolski, D-Day Remembered: The Normandy Landings in American Collective Memory (Knoxville: University of Tennessee Press, 2016), 76-78.

${ }^{71}$ Belfast Telegraph, January 9, 1980, 9.

${ }^{72}$ For further discussion about Yanks, see Simpson, 'Yanks and Popular Memory'.

${ }^{73}$ See Sam Edwards, Allies in Memory: World War II and the Politics of Transatlantic

Commemoration, c. 1941-2001 (Cambridge: Cambridge University Press, 2015), 203-207.

${ }^{74}$ Edwards, Allies in Memory, 187-89. 
${ }^{75}$ Studs Terkle, 'The Good War': An Oral History of World War II (London: Hamish and Hamilton, 1984).

${ }^{76}$ Paris, Repicturing the Second World War, 9. For the late twentieth-century consolidation of the Good War idea in the US, see John Bodnar, The Good War in American Memory

(Baltimore: Johns Hopkins University Press, 2010).

${ }^{77}$ See Connelly, We Can Take it!, 271-73.

${ }^{78}$ See https://www.npg.org.uk/collections/search/portrait/mw251471/Gone-with-the-WindRonald-Reagan-Margaret-Thatcher (accessed April 5, 2019).

${ }^{79}$ See Simon Duke, US Defence Bases in the United Kingdom, 177; Jill Liddington, The Long Road to Greenham: Feminism and Anti-Militarism in Britain since 1820 (London: Virago Press, 1989), esp. 264-86; Robert Jackson, Strike Force: The USAF in Britain since 1948 (London: Robson Books, 1986), 142-53.

${ }^{80}$ For details about this series, see Sam Edwards, ' 12 O'Clock High and the Image of American Air Power, c.1946-1967' in Anna Froula and Stacy Takacs, eds, American Militarism on the Small Screen (Abingdon: Routledge, 2016), 46-62.

${ }^{81}$ For the post-1970 gendered shift in Second World War television drama, see Webster, 'Rose-Tinted Blighty', 13-14. Elements of the 'People's War' narrative were also reinvigorated in the 1970 s by the popular documentary series, The World at War. For some details about the series, see James Chapman, 'Television and History: The World at War', Historical Journal of Film, Radio and Television, 31, no. 2 (2011), 247-75.

${ }^{82}$ Belfast Telegraph, February 13, 1982, 9.

${ }^{83}$ Connelly, We Can Take It!, 189.

${ }^{84}$ Stage and Television Today, March 18, 1982, 20; June 17, 1982, 22; April 29, 1982, 18.

${ }^{85}$ Reynolds, Rich Relations, 220-21. 
${ }^{86}$ That said, the subject had received some attention in novels. See, for instance, Nevil Shute's The Chequer Board (London: William Heinemann Ltd, 1947) and William GardnerSmith's The Last of the Conquerors (New York: New American Library, 1948).

Significantly, the presence in wartime Britain of African American servicewomen has been even more marginalised, and the first film to acknowledge their presence was not released until 2019; it tells the story of the 6888th Central Postal Directory Battalion, a unit of 850 African American servicewomen stationed in Birmingham in February 1945. See The Six Triple Eight (2019).

${ }^{87}$ See Graham Smith, When Jim Crow Met John Bull: Black American Soldiers in World War II Britain (London: I.B. Tauris, 1987).

${ }^{88}$ Dimbleby and Reynolds, An Ocean Apart, 149.

${ }^{89}$ It is worth noting, however, that the lead American in A Canterbury Tale (1944), played by Sergeant John Sweet, donated his \$2,000 fee for the film to the African American civil rights group, the National Association for the Advancement of Colored People. See John Sweet, as reported in an interview in the early 2000s: http://www.powellpressburger.org/Trips/NewYork/20020816/NY02.html (accessed April 1, 2019). ${ }^{90}$ By the 1960 s, race would also structure and inform Anglo-American relations in other ways, most notably in the transatlantic comparisons drawn by the likes of Enoch Powell in his infamous 'Rivers of Blood' speech, but also by those seeking to contest racial discrimination in both the United States and Britain. For a full account of the response and reaction to Powell's speech, see Shirin Hirsch, In the Shadow of Enoch Powell: Race, Locality and Resistance (Manchester: Manchester University Press, 2018). For details about the place and role of race in transatlantic relations see Robin D.G. Kelly and Stephen Tuck, eds, The Other Special Relationship: Race, Rights and Riots in Britain and the United States (London: Palgrave, 2015). 
${ }^{91}$ See Neil Wynn, The Afro-American and the Second World War (New York: Holmes and Meier, 1976); Smith, When Jim Crow Met John Bull. The subject of the black American presence in Britain, and of relationships with local people, has recently been the subject of detailed attention. See Lucy Bland "Interracial Relationships and the "Brown Baby Question" Black GIs, White British Women and their Mixed Race Offspring in World War 11', Journal of the History of Sexuality, 26, no. 3 (2017); Lucy Bland, Britain's 'Brown Babies': the stories of children born to black GIs and British women in the second world war (Manchester: Manchester University Press, 2019). See also Clive Webb, 'Special Relationships: mixed-race couples in post-war Britain and the United States', Women's History Review, 26, no. 1 (2016), 110-29; Simon Topping, “"The Dusky Doughboys”: Interaction between African American soldiers and the population of Northern Ireland during the Second World War', Journal of American Studies, 47, no. 4 (2013), 1131-54.

${ }^{92}$ For full details about how the story told in Memphis Belle (1990) changed during the production process, and about how the usual elements of a 'friendly invasion' narrative were cut, see Memphis Belle files (part of the David Putnam collection) DTP-1-32-1-3-1 to DTP1-32-1-3-7, British Film Institute (BFI), London.

${ }^{93} \mathrm{Jim}$ Crow in Britain has also been explored in the ITV detective drama, Foyle's War. A 2010 episode - 'Killing Time' - effectively merged the plot of The Affair and Yanks via a story of an affair between a British woman, Mandy, and a black GI, Gabe. Beaten up by white soldiers for dancing in public with Mandy, and later arrested for her murder, Gabe is ultimately proven innocent by the dogged Foyle, thereby ensuring that he can take his young daughter (by Mandy) home to New York once the war is done. But such examinations of wartime racism, British accommodation of segregation, and of inter-racial love, sex and romance remain few and far between.

${ }^{94}$ See, for example, Costigliola, ‘ 'Unceasing Pressure for Penetration',1309-39. 
${ }_{95}$ The most recent televisual exploration of the friendly invasion, Our Mother and Other Strangers (BBC, 2016) similarly avoids examining the segregation of African American personnel. 